\title{
Potassium, calcium, and zinc phosphites on white mold control in soybean
}

\author{
Andersom Milech Einhardt ${ }^{1}$ (D), Gabriel Martins Falcão Souza ${ }^{1}$ (D), Patricia Ricardino Silveira ${ }^{1}$ (D), \\ Fabrício Ávila Rodrigues ${ }^{1, \star}$ \\ 1. Universidade Federal de Viçosa - Departamento de Fitopatologia - Viçosa (MG), Brazil.
}

\begin{abstract}
White mold, caused by Sclerotinia sclerotiorum, is one the most devastating disease on soybean worldwide. Considering the potential of phosphites to protect plants against different diseases, this study investigated the possibility of using potassium (K), calcium (Ca), and zinc ( $\mathrm{Zn}$ ) phosphites for white mold control in soybean. The contact effect of the phosphites on fungal mycelial growth was evaluated in vitro. In the greenhouse study, plants were inoculated with S. sclerotiorum at $48 \mathrm{~h}$ after being sprayed with water (control), $\mathrm{K}$, $\mathrm{Ca}$, and $\mathrm{Zn}$ phosphites by using an agar plug $\left(0.8 \mathrm{~cm}^{2}\right)$ containing fungal mycelia. Lesion area of white mold and chlorophyll (Chl) a fluorescence parameters were evaluated on the leaflets of plants at $96 \mathrm{~h}$ after inoculation. The Chl a parameters were also evaluated in noninoculated leaflets at the same time. Fungal mycelial growth was abundant in the absence of phosphites, but inhibited in the presence of the three phosphites indicating their direct effect. The lesion area in the leaflets of plants sprayed with $\mathrm{K}, \mathrm{Ca}$, and $\mathrm{Zn}$ phosphites were 90,98 , and $68 \%$ lower, respectively, compared to plants sprayed with water. The functionality of the photosynthetic apparatus was more preserved on the leaflets of plants sprayed with phosphites due to the lower lesions size, especially for the Ca phosphite. In conclusion, the $\mathrm{K}, \mathrm{Ca}$, and $\mathrm{Zn}$ phosphites were effective in reducing white mold symptoms mainly through a contact effect on the fungal mycelial growth
\end{abstract}

Key words: Glycine max, Sclerotinia sclerotiorum, alternative disease control, photosynthesis.

\author{
Received: \\ Apr. 06, 2020 \\ Accepted: \\ May. 21, 2020 \\ Section Editor: \\ Gabriel Constantino Blain \\ ${ }^{*}$ Corresponding author: \\ fabricio@ufv.br
}

Soybean [Glycine max (L.) Merrill] is affected by several diseases, but the occurrence of white mold, caused by the fungus Sclerotinia sclerotiorum (Lib.) de Bary, is one the most difficult to manage (Hegedus and Rimmer 2005). In Brazil, white mold is prevalent on soybean grown in regions with elevations higher than $600 \mathrm{~m}$ (Meyer et al. 2014). Water-soaked lesions displaying white cottony fungal mycelium on the leaf surface of soybean, regardless of the growth stage, is the major white mold symptoms (Link and Johnson 2007). There is an abundant production of sclerotia formed from mycelia of S. sclerotiorum, ensuring its survival in the soil for several years (Link and Johnson 2007; Mueller et al. 2015). The absence of soybean cultivars resistant to white mold makes its control a challenge (Kim and Diers 2014; Mueller et al. 2015) which will be greatly dependent on fungicides spray (Sumida et al. 2015) and cultural methods (e.g., crop rotation, tillage, wide row spacing, planting date, and weed control) (Link and Johnson 2007; Mueller et al. 2015). The use of fungicides brings a series of problems such as the negative impact on human health and environment, increase the production cost, and the emergence of S. sclerotiorum isolates resistant to them (Mueller et al. 2002; Lehner et al. 2015).

New alternatives for white mold management need to be discovered by the researchers. Phosphites, a reduced form of phosphate $\left(\mathrm{PO}_{4}^{3-}\right)$, are composed of a phosphorous acid salt that is systemically mobile in the plant and has been shown to control diseases in several economically crops (Smillie et al. 1989; Brackmann et al. 2004; Peruch and Bruna 2008; Dianese et al. 2009; Nojosa et al. 2009; Araújo et al. 2010, 2015; Fagundes-Nacarath et al. 2018). Fungal mycelial growth 
and sporulation of pathogens can be both directly affected by phosphites or the host defense responses (e.g., production of phenolics, phytoalexins, and lignin as well as high activities of chitinase, $\beta$-1,3-glucanase, peroxidase, polyphenoloxidase, and phenylalanine ammonia-lyase) activity can be activated by them (Panicker and Gangadharan 1999; Daniel and Guest 2005; Dalio et al. 2014; Novaes et al. 2019; Fagundes-Nacarath et al. 2018).

Considering the lack of information in the literature regarding the physiological changes in soybean plants sprayed with phosphites and infected with S. sclerotiorum, the present study aimed to examine the effect of potassium (K), calcium $(\mathrm{Ca})$, and zinc $(\mathrm{Zn})$ phosphites on the photosynthetic performance of the plants challenged or not with S. sclerotiorum by examining chlorophyll (Chl) $a$ fluorescence parameters.

For the in vitro study, one disk $\left(0.8 \mathrm{~cm}^{2}\right)$ of potato-dextrose-agar (PDA) medium containing mycelia of $S$. sclerotiorum was transferred to the center of a Petri dish containing PDA medium amended with $\mathrm{K}, \mathrm{Ca}$, and $\mathrm{Zn}$ phosphites at the concentration of $7.5 \mathrm{~mL} \cdot \mathrm{L}^{-1}$. The plates were kept in an incubator with the temperature of $25^{\circ} \mathrm{C}$ and photoperiod of $12 \mathrm{~h}$. Mycelial growth was measured at 48 and $72 \mathrm{~h}$ after deposition of the PDA disks using a digital pachymeter. The in vitro study was conducted in a completely randomized design with four treatments [control (water), $\mathrm{K}$ phosphite $\left(30 \% \mathrm{P}_{2} \mathrm{O}_{5}\right.$ and $20 \% \mathrm{~K})$, Ca phosphite $\left(30 \% \mathrm{P}_{2} \mathrm{O}_{5}\right.$ and $\left.7 \% \mathrm{Ca}\right)$, and $\mathrm{Zn}$ phosphite $\left(40 \% \mathrm{P}_{2} \mathrm{O}_{5}\right.$ and $\left.\left.10 \% \mathrm{Zn}\right)\right]$, six replications, and repeated.

In the greenhouse study, soybean plants (cultivar TMG135, susceptible to S. sclerotiorum) were grown in plastic pots containing $2 \mathrm{~kg}$ of substrate (Vida Verde, Mogi Mirim, SP, Brazil). Plants at the R5.3 growth stage, kept in a greenhouse (temperature of $28 \pm 3{ }^{\circ} \mathrm{C}$, relative humidity of $75 \% \pm 5$, and natural radiation), were sprayed with solutions ( $15 \mathrm{~mL}$ per plant) of $\mathrm{K}, \mathrm{Ca}$, and $\mathrm{Zn}$ phosphites at the concentration of $7.5 \mathrm{~mL} \cdot \mathrm{L}^{-1}$ (K Phytogard, Ca Phytogard, and Zn Phytogard; Stoller do Brasil S.A., Cosmópolis, Brazil). The $\mathrm{pH}$ of the phosphites solutions was adjusted to 5.5 using $\mathrm{HCl} 1 \mathrm{M}$ before spray. Plants sprayed with water served as the control treatment. Inoculum of S. sclerotiorum was produced according to Novaes et al. (2019). At two days after spray, an agar plug $\left(0.8 \mathrm{~cm}^{2}\right)$ containing fungal mycelia was deposited on the adaxial surface of leaflets (two leaflets per plant and one agar plug per leaflet). After inoculation, plants were kept in a plastic mist growth chamber (temperature of $25 \pm 3{ }^{\circ} \mathrm{C}$ and relative humidity of $90 \pm 5 \%$ ) inside a greenhouse during the experiments.

The inoculated leaflets from two leaves of each plant per replication of each treatment were collected at $96 \mathrm{~h}$ after inoculation (hai), scanned at $600 \mathrm{dpi}$, and the images obtained were processed using the QUANT software (FagundesNacarath et al. 2018) to determine the values of lesion area. The Chl $a$ fluorescence parameters were obtained on the third leaflet of each plant per replication of each treatment (five leaflets per treatment) at 96 hai by using the Imaging-PAM image fluorometer and the Imaging Win software MAXI version (Heinz Walz GmbH, Effeltrich, Germany) following the procedures described by Fagundes-Nacarath et al. (2018) changing the time of actinic photon irradiance to obtain the steady-state fluorescence yield that was fixed in $5 \mathrm{~min}$.

The experiment was arranged in a completely randomized design with five treatments [plants sprayed with water and non-inoculated (control NI), plants sprayed with water and inoculated (I) (control I), plants sprayed with K phosphite and I, plants sprayed with Ca phosphite and I, and plants sprayed with Zn phosphite and I], five replications, and repeated. Each experimental unit consisted of a plastic pot containing four plants. Data from the variables and parameters evaluated were checked for normality and homogeneity of variance, analyzed using the MIXED procedure of SAS software (Release 8.02 Level $02 \mathrm{M} 0$ for Windows, SAS Institute) to determine if data from these two experiments could be combined (Moore and Dixon 2015), and then submitted to analysis of variance. Means of treatments were compared by F and Tukey tests $(p \leq 0.05)$ by using the Minitab software v. 18.

Mycelial growth of S. sclerotiorum was abundant at $72 \mathrm{~h}$ after incubation in the Petri dishes from the control treatment (Fig. 1a) compared to the dishes containing PDA with the addition of $\mathrm{K}, \mathrm{Ca}$, and $\mathrm{Zn}$ phosphites (Fig. 1b-d). At $48 \mathrm{~h}$ after incubation, fungal mycelial growth was significantly lower by 85,94 , and $94 \%$ for $\mathrm{Ca}$, Zn, and $\mathrm{K}$ phosphites, respectively, in comparison to the control treatment (Fig. 2). At $72 \mathrm{~h}$ after incubation, fungal mycelial growth was significantly lower by 94,98 e $98 \%$ for $\mathrm{Ca}, \mathrm{Zn}$, and $\mathrm{K}$ phosphites, respectively, in comparison to the control treatment (Fig. 2). The lesions of white mold were of great extension on the leaflets of plants from the control treatment in comparison to what was noticed on the leaflets of plants from the $\mathrm{K}, \mathrm{Ca}$, and $\mathrm{Zn}$ phosphites (Fig. 3a). The lesion area was reduced by 90,98 , and $68 \%$ for the $\mathrm{K}, \mathrm{Ca}$, and $\mathrm{Zn}$ phosphites, respectively, in comparison to the control treatment (Fig. 3b). 

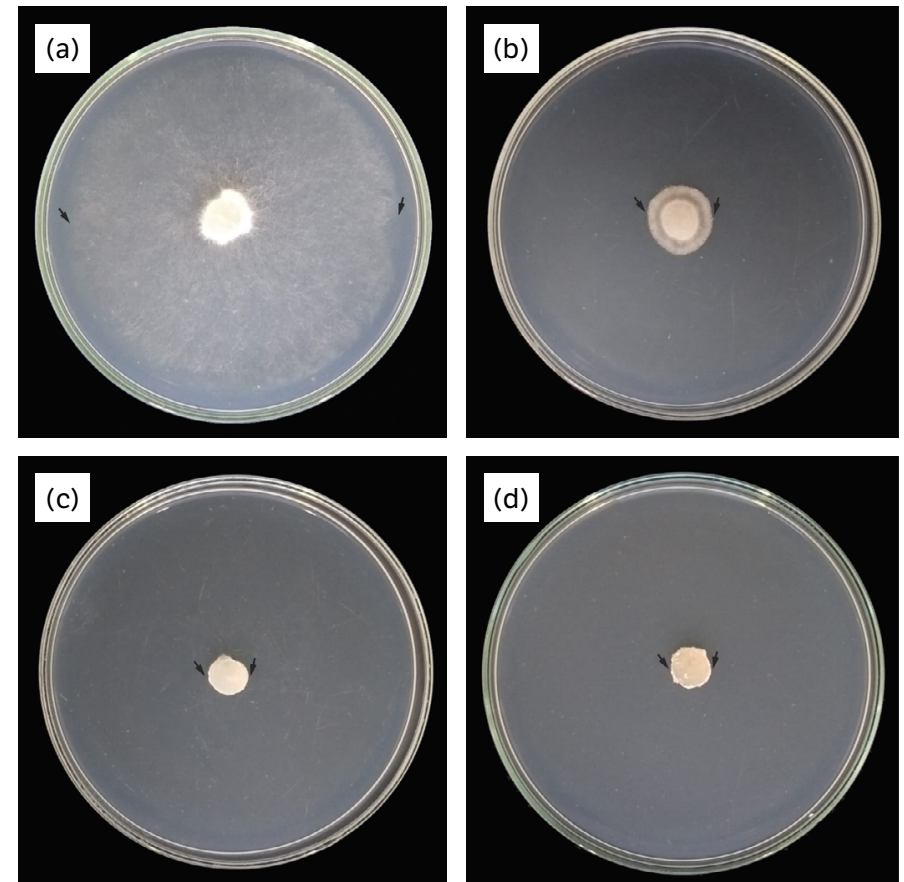

Figure 1. Mycelial growth of Sclerotinia sclerotiorum in potato-dextrose-agar (PDA) medium without addition of phosphite (control) (a) and with the addition of potassium phosphite (b), calcium phosphite (c), and zinc phosphite (d) at $72 \mathrm{~h}$ after deposition of the PDA disks containing fungal mycelia. The arrows indicate the end of the fungal mycelial growth.

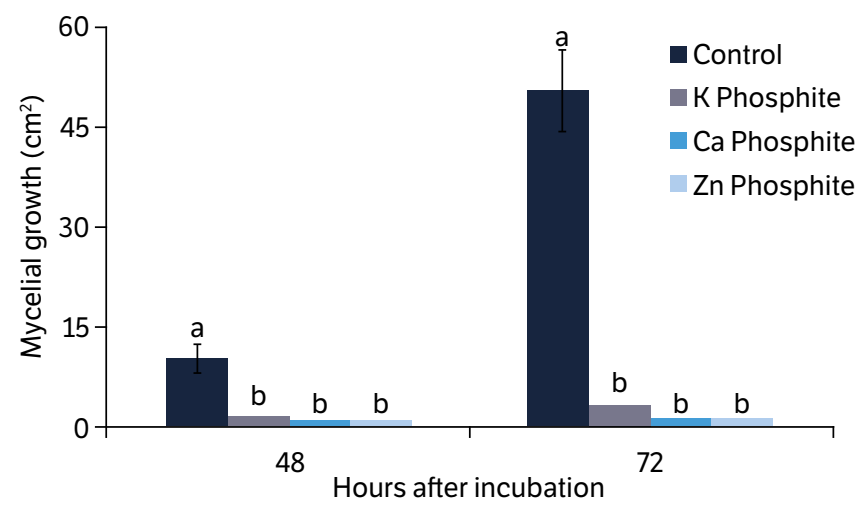

Figure 2. Mycelial growth of Sclerotinia sclerotiorum in potato-dextrose-agar (PDA) medium without addition of phosphite (control) and with the addition of $7.5 \mathrm{~mL} \cdot \mathrm{L}^{-1}$ of potassium (K), calcium ( $\left.\mathrm{Ca}\right)$, and zinc $(\mathrm{Zn})$ phosphites. Means for each treatment followed by different letters, at each evaluation time, are significantly different $(p \leq 0.05)$ according to Tukey's test. The bars represent the standard error of the means.

Images of $\mathrm{Chl} a$ fluorescence on the leaflets obtained from noninoculated plants did not show any difference among the treatments regarding color patterns for the parameters $F_{v} / F_{\mathrm{m}}, \mathrm{Y}(\mathrm{II}), \mathrm{Y}(\mathrm{NPQ})$, and $\mathrm{Y}(\mathrm{NO})$ (Fig. 4). Alterations in the images of $\mathrm{Chl} a$ fluorescence parameters were more drastic on the inoculated leaflets of plants sprayed with water as well on inoculated leaflets of plants sprayed with either $\mathrm{K}$ and $\mathrm{Zn}$ phosphites in comparison to inoculated leaflets of plants sprayed with the Ca phosphite (Fig. 4). For inoculated leaflets, $F_{\mathrm{v}} / F_{\mathrm{m}}$ was significantly higher by 19, 32, and 7\%, respectively, for K, Ca, and $\mathrm{Zn}$ phosphites treatments in comparison to the control treatment (Fig. 5A). Y(NPQ) was significantly higher by 26 and $18 \%$ for Ca and $\mathrm{Zn}$ phosphites treatments in comparison to the control treatment considering the inoculated leaflets (Fig. 5B). For inoculated leaflets, Y(II) was significantly higher by 119 and $215 \%$ for $\mathrm{K}$ and Ca phosphites treatments, respectively, in comparison to the control treatment (Fig. 5C). Regarding the $\mathrm{Y}(\mathrm{NO}$ ), there were significant reductions of 46, 26, and 16\% for Ca, $\mathrm{K}$, and $\mathrm{Zn}$ phosphites treatments, respectively, in comparison to the control treatment considering the inoculated leaflets (Fig. 5D). 
(a)
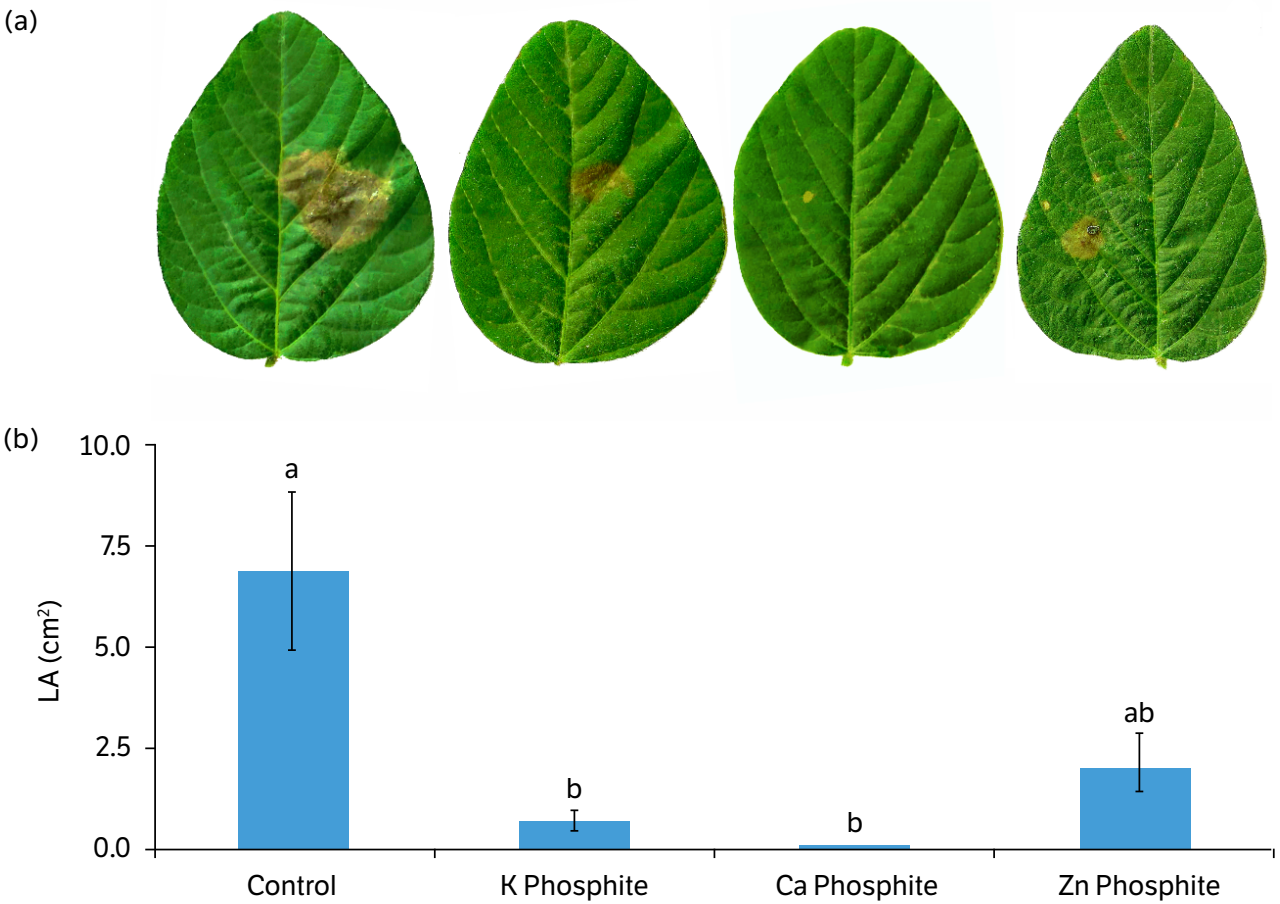

Means for each treatment followed by different letters are statistically different $(p \leq 0.05)$ according to Tukey's test. The bars represent the standard error of the means. Figure 3. Lesions of white mold (a) and lesion area (LA) (b) in the leaflets of soybean plants sprayed with water (control) or with potassium $(\mathrm{K})$, calcium ( $\mathrm{Ca})$, and zinc ( $\mathrm{Zn})$ phosphites at $96 \mathrm{~h}$ after inoculation with Sclerotinia sclerotiorum.

0 0.5 1

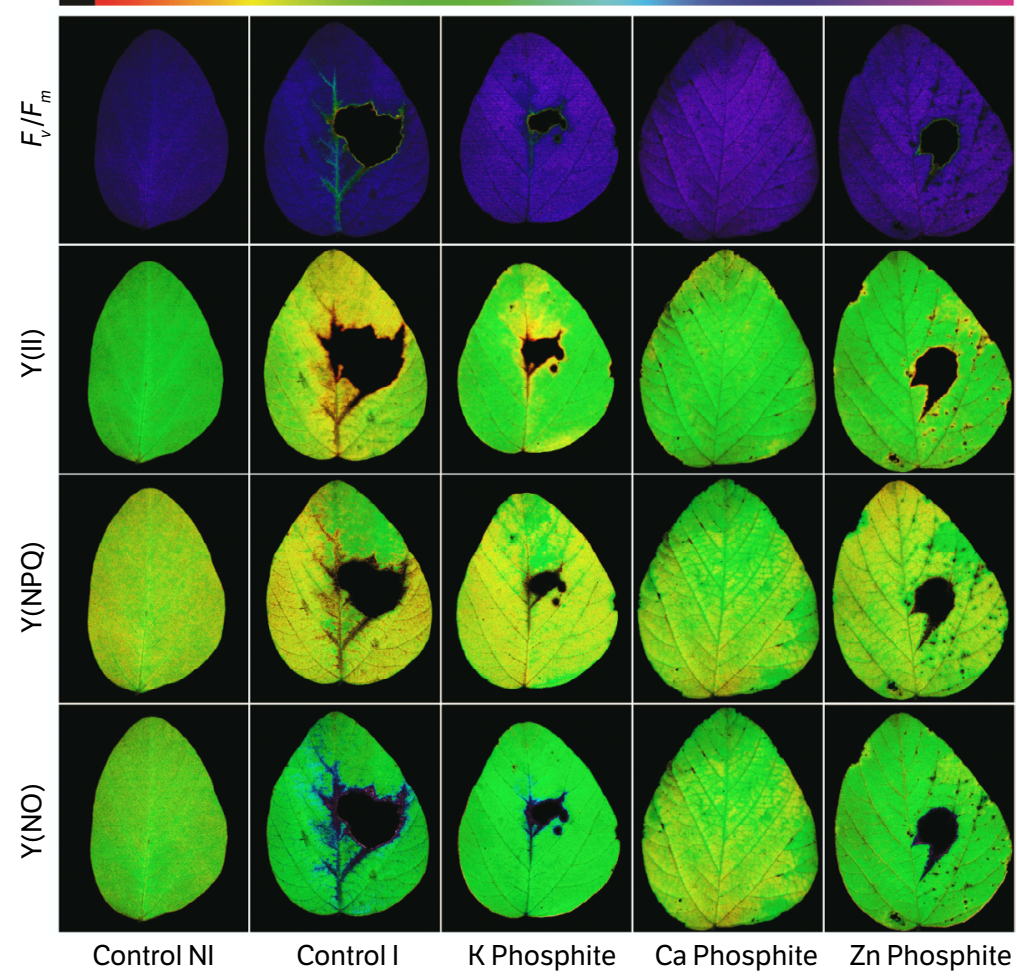

Data was obtained at $96 \mathrm{~h}$ after inoculation with S. sclerotiorum.

Figure 4. Images of the chlorophyll a fluorescence parameters maximum photochemical efficiency of photosystem II (PSII) $\left(F_{\mathrm{v}} / F_{\mathrm{m}}\right)$, effective yield of PSII [Y(II)], yield for dissipation by down-regulation energy [Y(NPQ)], and yield for other nonphotochemical (non-regulated) losses [Y(NO)] on the leaflets of soybean plants submitted to the following treatments: water spray (control) and noninoculation ( $\mathrm{NI})$, control and inoculation with Sclerotinia sclerotiorum (I), potassium (K) phosphite spray and I, calcium (Ca) phosphite spray and I, and zinc (Zn) phosphite spray and I. 

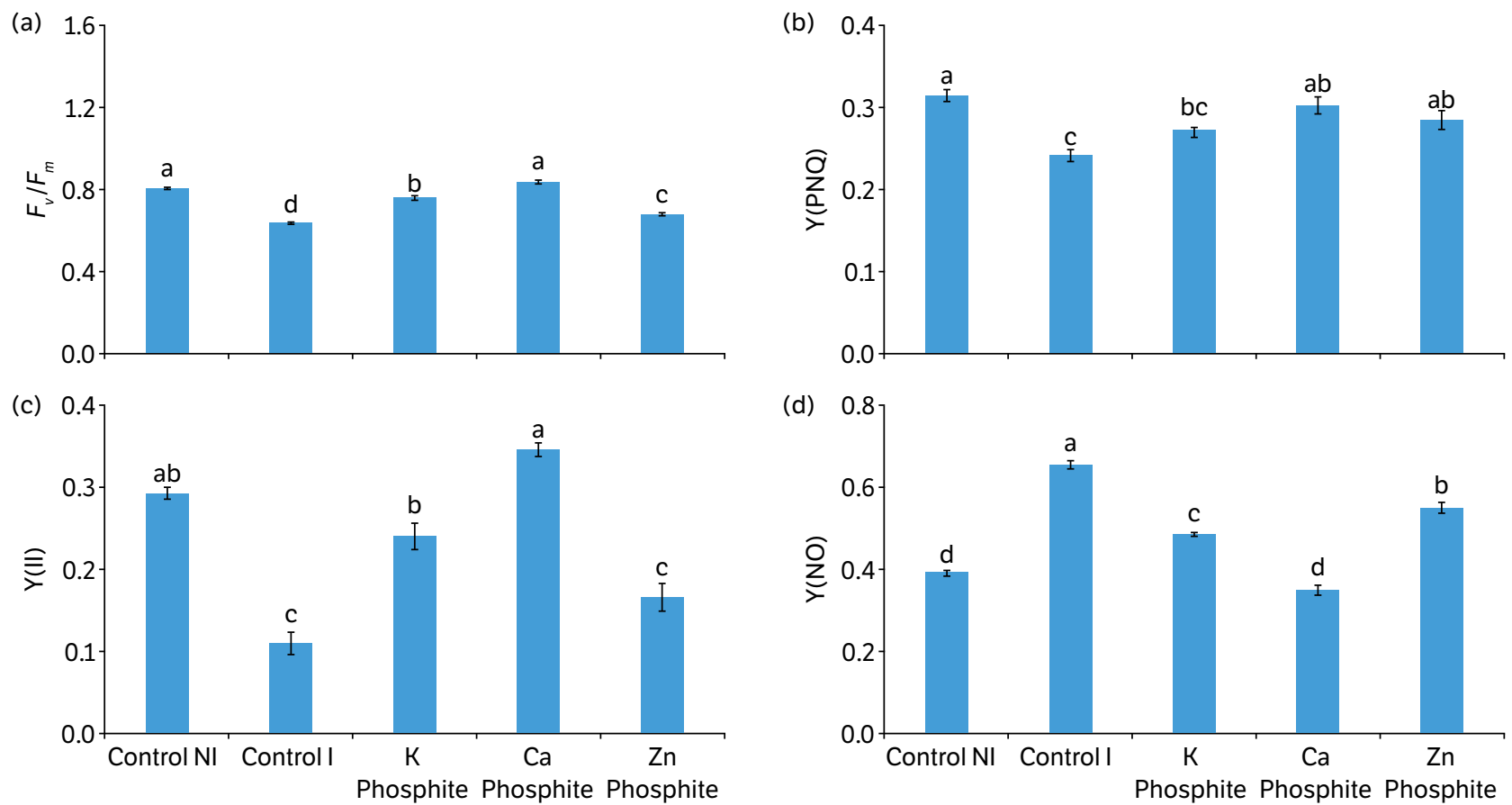

Data was obtained at $96 \mathrm{~h}$ after inoculation with S. sclerotiorum. Means for each treatment followed by different letters are significantly different ( $p \leq 0.05$ ) according to Tukey's test. The bars represent the standard error of the means.

Figure 5. Chlorophyll a parameters: maximum photosystem II quantum efficiency $\left(F_{v} / F_{\mathrm{m}}\right)$, photochemical yield [Y(II)], yield for dissipation by down-regulation [Y(NPQ)], and yield for other nonphotochemical (nonregulated) losses [Y(NO)] determined on the leaflets of soybean plants submitted to the following treatments: water spray (control) and non-inoculation (NI), control and inoculation with Sclerotinia sclerotiorum (I), potassium (K) phosphite spray and I, calcium (Ca) phosphite spray and I, and zinc (Zn) phosphite spray and I.

Based on the in vitro study, it was possible to notice a contact effect of the phosphites on mycelial growth of S. sclerotiorum. Araújo et al. (2010) reported a similar response for the K phosphite that inhibited the mycelial growth of Colletotrichum gloeosporioides. In the greenhouse study, the lowest lesioned leaf area for plants sprayed with phosphites evidenced the effect of their ions on white mold control. Phosphites showed a positive effect in controlling Botrytis spp., C. gloeosporioides, Penicillium spp., and Rhizopus spp. in apple (Araújo et al. 2010; Brackmann et al. 2004), Phytophthora palmivora in papaya (Dianese et al. 2009), and Plasmopara viticola in grape (Pereira et al. 2012). It should be noted that the dose used in the in vitro study was the same used to spray the plants cultivated in the greenhouse. However, fungal mycelia were probably exposed to a lower phosphite concentration on the leaflets of plants from the greenhouse condition in comparison to the in vitro assay. In the greenhouse conditions, phosphites were applied at $48 \mathrm{~h}$ before fungal inoculation, and their absorption and mobilization occurred in the plant tissues. Thus, considering that the contact effect becomes much more pronounced in the in vitro condition compared to the greenhouse condition, phosphites may have acted not only by contact but also on the potentiation of host defense responses against $S$. sclerotiorum infection.

Plants sprayed with Ca phosphite and infected with S. sclerotiorum showed adjustments in light energy dissipation differently from infected plants not receiving phosphite spray. The maintenance of the values of $F_{\mathrm{v}} / F_{\mathrm{m}}$ and Y(II) in the inoculated plants sprayed with Ca phosphite similarly to what was obtained for noninoculated plants demonstrates that the energy absorbed by the light-harvesting complex of the photosystems remained directed towards the photochemical processes. The great lesion area on the leaflets of inoculated plants resulted in lower Y(NPQ) values, and an increase on Y(NO) values suggesting that the ability of plants to regulate the dissipation of excess energy was negatively affected leading to an increase in the dissipation of energy via an unregulated process. Similar damage to the photosynthetic apparatus caused by S. sclerotiorum has been observed by Yang et al. (2014) in tobacco and by Fagundes-Nacarath et al. (2018) in common bean. The increase in $\mathrm{Y}(\mathrm{NO})$ values is associated with a high production of reactive oxygen species, which can lead to an increase in damage to photosystems and other cellular constituents (Klughammer and Schreiber 2008; Huang et al. 2018). Although the $\mathrm{K}$ and $\mathrm{Zn}$ phosphites did not provide the same magnitude of disease control and preservation of the photosynthetic 
process as noticed by Ca phosphite, they were both important to maintain the values of the photosynthetic parameters on infected leaflets similarly to those observed for non-inoculated plants. The effect of the phosphites in reducing the lesioned area in the soybean leaves infected by S. sclerotiorum and preserving their photosynthetic apparatus highlight their potential to maintain the high capacity for the synthesis of energetic compounds even in the occurrence of white mold.

In conclusion, the $\mathrm{K}, \mathrm{Ca}$, and $\mathrm{Zn}$ phosphites were effective in reducing white mold symptoms mainly through a contact effect on fungal mycelial growth. Moreover, the functionality of the photosynthetic apparatus was more preserved on the leaflets of plants sprayed with phosphites due to a reduction in lesions size.

\section{FUNDING}

Conselho Nacional de Desenvolvimento Científico e Tecnológico

[http://doi.org/10.13039/501100003593]

Fundação de Amparo à Pesquisa do Estado de Minas Gerais

[http://doi.org/10.13039/501100004901]

Coordenação de Aperfeiçoamento de Pessoal de Nível Superior

Finance Code 001

[http://doi.org/10.13039/501100002322]

\section{AUTHOR'S CONTRIBUTION}

Conceptualization, Einhardt A. M., Souza G. M. F. and Rodrigues F. A.; Methodology, Einhardt A. M. and Souza G. M. F.; Investigation, Einhardt A. M., Souza G. M. F. and Silveira P. R.; Writing - Original Draft, Einhardt A. M. and Souza G.M.F.; Writing - Review and Editing, Einhardt A. M. and Rodrigues F. A.; Funding Acquisition, Rodrigues F. A.; Resources, Rodrigues F. A.; Supervision, Rodrigues F. A.

\section{REFERENCES}

Araújo, L., Bispo, W. M. S., Rios, V. S., Fernandes, S. A. and Rodrigues, F. A. (2015). Induction of the phenylpropanoid pathway by acibenzolar-s-methyl and potassium phosphite increases mango resistance to Ceratocystis fimbriata infection. Plant Disease, 99, 447459. https://doi.org/10.1094/PDIS-08-14-0788-RE

Araújo, L., Valdebenito-Sanhueza, R. M. and Stadnik, M. J. (2010). Avaliação de formulações de fosfito de potássio sobre Colletotrichum gloeosporioides in vitro e no controle pós-infeccional da mancha foliar de Glomerella em macieira. Tropical Plant Pathology, $35,54-59$. https://doi.org/10.1590/S1982-56762010000100010

Brackmann, A., Giehl, R. F. H., Sestari, I. and Steffens, C. A. (2004). Fosfitos para o controle de podridões pós-colheita em maçãs 'Fuji' durante o armazenamento refrigerado. Ciência Rural, 34, 1039-1042. https://doi.org/10.1590/S0103-84782004000400011

Dalio, R. J. D., Fleischmann, F., Humez, M. and Oswald, W. (2014). Phosphite protects Fagus sylvatica seedlings towards Phytophthora plurivora via local toxicity, priming and facilitation of pathogen recognition. PLoS ONE 9, e87860. https://doi.org/10.1371/journal. pone.0087860

Daniel, R. and Guest, D. (2005). Defence responses induced by potassium phosphonate in Phytophthora palmivora-challenged Arabidopsis thaliana. Physiological and Molecular Plant Pathology, 67, 194-201. https://doi.org/10.1016/j.pmpp.2006.01.003 
Dianese, A. C., Blum, L. E. B., Dutra, J. B. and Lopes, L. F. (2009). Aplicação de fosfito de potássio, cálcio ou magnésio para a redução da podridão-do-pé do mamoeiro em casa de vegetação. Ciência Rural, 39, 2309-2314. https://doi.org/10.1590/S0103-84782009000800006

Fagundes-Nacarath, I. R. F., Debona, D. and Rodrigues, F. A. (2018). Oxalic acid-mediated biochemical and physiological changes in the common bean-Sclerotinia sclerotiorum interaction. Plant Physiology and Biochemistry, 129, 109-121. https://doi.org/10.1016/j. plaphy.2018.05.028

Link, V. H. and Johnson, K. B. (2007). White mold. The Plant Health Instructor. https://doi.org/10.1094/PHI-I-2007-0809-01

Hegedus, D. D. and Rimmer, S. R. (2005). Sclerotinia sclerotiorum: When "to be or not to be" a pathogen? FEMS Microbiology Letters, 251, 177-184. https://doi.org/10.1016/j.femsle.2005.07.040

Huang, W., Tikkanen, M. and Zhang, S.-B. (2018). Photoinhibition of photosystem I in Nephrolepis falciformis depends on reactive oxygen species generated in the chloroplast stroma. Photosynthesis Research, 137,129-140. https://doi.org/10.1007/s11120-018-0484-1

Kim, H. S. and Diers, B. W. (2014). Inheritance of partial resistance to sclerotinia stem rot in soybean. Crop Science, 40, 55-61. https:// doi.org/10.2135/cropsci2000.40155x

Klughammer, C. and Schreiber, U. (2008). Complementary PS II quantum yields calculated from simple fluorescence parameters measured by PAM fluorometry and the Saturation Pulse method. PAM Application Notes, 1, 27-35.

Lehner, M. S., Paula Junior, T. J., Silva, R. A., Vieira, R. F., Carneiro, J. E. S., Schnabel, G. and Mizubuti, E. S. G. (2015). Fungicide sensitivity of Sclerotinia sclerotiorum: A thorough assessment using discriminatory dose, $\mathrm{EC}_{50}$, high-resolution melting analysis and description of new point mutation associated with thiophanate-methyl resistance. Plant Disease, 99, 1537-1543. https://doi.org/10.1094/PDIS-11-14-1231-RE

Meyer, M. C., Campos, H. D., Godoy, C. V. and Utiamada, C. M. (2014). Ensaios cooperativos de controle químico de mofo branco na cultura da soja: safras 2009 a 2012 [Documentos 345]. Londrina: Embrapa Soja. [Accessed Mar. 30, 2020]. Available at: https://www.infoteca. cnptia.embrapa.br/bitstream/doc/985018/1/Ensaioscooperativosdecontrolequimicodemofobranconaculturadasojasafras2009a2012.pdf

Moore, K. J. and Dixon, P. M. (2015). Analysis of combined experiments revisited. Agronomy Journal, 107,763-771. https://doi.org/10.2134/ agronj13.0485

Mueller, D. S., Dorrance, A. E., Derksen, R. C., Ozkan, E., Kurle, J. E., Grau, C. R., Gaska, J. M., Hartman, G. L., Bradley, C. A. and Pedersen, W. L. (2002). Efficacy of fungicides on Sclerotinia sclerotiorum and their potential for control of sclerotinia stem rot on soybean. Plant Disease, 86, 26-31. https://doi.org/10.1094/PDIS.2002.86.1.26

Mueller, D. S., Bradley, C., Chilvers, M., Esker, P., Malvick, D., Peltier, A., Sisson, A. and Wise, K. (2015). Soybean disease management: White mold. Crop Protection Network, 1005. [Accessed Jun. 10, 2018]. Available at: https://crop-protection-network.s3.amazonaws. com/publications/cpn-1005-white-mold.pdf

Nojosa, G. B. A., Resende, M. L. V., Barguil, B. M., Moraes, S. R. G. and Vilas Boas, C. H. (2009). Efeito de indutores de resistência em cafeeiro contra a mancha de Phoma. Summa Phytopathologica, 35, 60-62. https://doi.org/10.1590/S0100-54052009000100011

Novaes, M. I. C., Debona, D., Fagundes-Nacarath, I. R. F., Brás, V. V. and Rodrigues, F. A. (2019). Physiological and biochemical responses of soybean to white mold affected by manganese phosphite and fluazinam. Acta Physiologiae Plantarum, 41,186. https://doi.org/10.1007/ s11738-019-2976-9

Panicker, S. and Gangadharam, K. (1999). Controlling downy mildew of maize caused by Peronosclerospora sorghi by foliar sprays of phosphonic acid compounds. Crop Protection, 18, 115-118. https://doi.org/10.1016/S0261-2194(98)00101-X

Pereira, V. F., Resende, M. L. V. D., Ribeiro Júnior, P. M., Regina, M. A., Mota, R. V. and Vitorino, L. R. R. (2012). Fosfito de potássio no controle do míldio da videira e características físico-químicas de uvas Merlot. Pesquisa Agropecuária Brasileira, 47, 1581-1588. https:// doi.org/10.1590/S0100-204X2012001100004 
Peruch, L. A. M. and Bruna, E. D. (2008). Relação entre doses de calda bordalesa e de fosfito potássico na intensidade do míldio e na produtividade da videira cv. 'Goethe'. Ciência Rural, 38, 2413-2418. https://doi.org/10.1590/S0103-84782008000900001

Smillie, R., Grant, B. R. and Guest, D. (1989). The mode of action of phosphite: evidence for both direct and indirect modes of action on three Phytophthora spp. in plants. Phytopathology, 79, 921-926. https://doi.org/10.1094/Phyto-79-921

Sumida, C. H., Canteri, M. G., Peitl, D. C., Tibolla, F., Orsini, I. P., Araújo, F. A., Chagas, D. F. and Calvos, N. S. (2015). Chemical and biological control of Sclerotinia stem rot in the soybean crop. Ciência Rural, 45, 760-766. https://doi.org/10.1590/0103-8478cr20140198

Yang, C., Zhang, Z., Gao, H., Liu, M. and Fan, X. (2014). Mechanisms by which the infection of Sclerotinia sclerotiorum (Lib.) de Bary affects the photosynthetic performance in tobacco leaves. BMC Plant Biology, 14, 240. https://doi.org/10.1186/s12870-014-0240-4 